\title{
No baú de Augusto Mina: o micro e o global na história do trabalho ${ }^{1}$
}

\author{
Henrique Espada Lima*
}

\section{RESUMO}

Este artigo discute as relaçóes entre a micro-história e o recente debate sobre a história global no campo dos estudos sobre o trabalho. $\mathrm{O}$ texto se desdobra em uma discussão historiográfica e uma análise empírica de um documento, o inventário judicial dos bens deixados por um africano livre de nome Augusto Mina, um marinheiro e trabalhador portuário, que morreu na cidade do Desterro, na Ilha de Santa Catarina, em 1861. O artigo discute o modo pelo qual a análise dos fatos que se conhece da vida de Augusto pode ilustrar as potencialidades e os limites de uma investigação histórica que tente integrar as sugestóes teóricas e metodológicas da micro-história aos desafios intelectuais propostos pela história global do trabalho.

Palavras-chave: história global; africanos livres; escravidão; trabalho compulsório.

\section{ABSTRACT}

This article discusses the relations between micro-history and the current debate about global history in the field of labor studies. The analysis includes both a historiographical discussion and an in-depth reading of a single document: the post-mortem inventory of the possessions left behind by the liberated African (africano livre) named Augusto Mina, a seaman and a longshoreman who died in 1861 in the city of Desterro, on the Island of Santa Catarina. The article explores how the revelations of Augusto's life's archival record can illustrate both the potential and the limits of a historical investigation that tries to integrate both the theoretical and methodological contributions of micro-history and the intellectual challenges of global labor history.

Keywords: global history; free Africans; slavery; bonded labor.

DOI - http://dx.doi.org/10.1590/2237-101X016031009

1 Uma versão anterior deste artigo foi publicada em inglês na revista Workers of the World (v. 1, n. 3, May 2013). O artigo original foi escrito durante minha estada como pesquisador visitante no Institute d'Études Avancées de Nantes em 2013, tendo se beneficiado também das discussóes que tive quando fui fellow no IGK "Arbeit und Lebenslauf in globalgeschichtlicher Perspektive" (Humboldt-Universität-zu-Berlin) em 2011-12. Agradeço a Christian de Vito por ter provocado a ideia inicial do artigo e aos pareceristas anônimos de Workers of the World e Topoi pelas sugestôes e críticas. Agradeço também a Amy Chazkel por sua leitura cuidadosa, e a Beatriz Mamigonian e Cristiana S. Pereira por seus comentários.

Artigo recebido em 27 de janeiro de 2015 e aprovado para publicação em 1 de setembro de 2015.

* Doutor em História pela Universidade Estadual de Campinas (Unicamp) e professor na Universidade Federal de Santa Catarina (UFSC). Florianópolis, SC, Brasil. E-mail: henrique.espada@ufsc.br. 
Augusto morreu no mar, na Ilha de Santa Catarina, em 25 de junho de 1861. Tinha entáo perto de 25 anos e trabalhava como marinheiro no porto do Desterro. ${ }^{2}$ Ele havia nascido na África e importado para a costa brasileira em 1850, quando foi apreendido pelas autoridades locais com outros companheiros de infortúnio. Na nova terra, e como consequência das leis que previam casos similares de apresamento de africanos ilegalmente escravizados, Augusto não seria considerado escravo mas sim aquilo que a legislação então chamava um "africano livre". Sob custódia e supervisão do Estado brasileiro, seu trabalho havia sido destinado a (ou arrematado por) um cidadáo privado, responsável pela sua temporária, ainda que longa, tutela. ${ }^{3}$

O africano morreu com uma reputação. Reputação esta que levou um oficial de polícia a sua casa na rua da Palma, na cidade do Desterro, com o objetivo de fazer um inventário dos seus pertences. Augusto morava com cinco outros homens pretos de diferentes condiçóes: os escravos Roque, Gregório, Francisco e João, assim como o liberto de nome Joaquim. Aparentemente, a razão do interesse pouco usual do subdelegado de polícia Antonio Mancio da Costa pelas posses de Augusto residia no rumor de que o jovem africano, morto sem deixar herdeiros, teria deixado atrás de si um montante desconhecido de dinheiro, mantido em um móvel que tinha no seu quarto.

Mancio da Costa chegou na pequena lojinha que Augusto alugava com seus companheiros, onde o preto Roque lhe apresentou um "banquinho" com uma gaveta trancada a chave. Aberta a gaveta, nela se continha três moedas de ouro e 33 de prata, assim como mais de duzentas notas de papel-moeda de diferentes valores, tudo somando um total de $438 \$ 000$ réis; uma quantia que no Desterro daqueles anos seria suficiente para comprar uma pequena casa, ou um terço do preço de um escravo que tivesse a idade de Augusto. Um dinheiro, de todo modo, raro de encontrar nas mãos de um trabalhador braçal ainda jovem, labutando lado a lado com outros homens como ele, africanos ou não, escravos em busca de pecúlio, ou libertos condicionais, trabalhando ao ganho no porto do Desterro, junto de outros homens pobres.

No mesmo dia em que visitou a morada de Augusto, o subdelegado também passou na

\footnotetext{
${ }^{2}$ Esta e todas as futuras referências sobre este caso foram retiradas de: "Inventário de Augusto Africano Livre" (executor: José da Lapa Souza Coentro). Fundo (em processo de organização): Juizo de Órfãos da Cidade do Desterro, 1861 - Arquivo do Museu do Judiciário Catarinense (Florianópolis, SC).

${ }^{3}$ Sobre os "africanos livres" no Brasil, o trabalho de referência mais completo continua sendo o de Beatriz G. Mamigonian, To be a Liberated African in Brazil: Labour and Citizenship in the Nineteenth Century. Tese (Doutorado em História) - University of Waterloo, Waterloo (CA), 2002. Outras referências importantes sobre o tema são: CONRAD, R. Neither Slave nor Free: The Emancipados of Brazil, 1818-1868. Hispanic American Historical Review, v. 53, n. 1, p. 50-70, 1973; BERTIN, Enidelce. Os meia-cara. Africanos livres em São Paulo no século XIX. Tese (Doutorado em História Social) - Universidade de São Paulo, São Paulo, 2006; MOREIRA, Alinnie S. Liberdade tutelada: os africanos livres e as relaçóes de trabalho na Fábrica de Pólvora da Estrela, Serra da Estrela (c. 1831-c.1870). Dissertaçáo (Mestrado em História) — Universidade Estadual de Campinas, Campinas, 2005.
} 
casa do tenente-coronel Manuel José Espíndola, o homem que havia arrematado os serviços do africano livre anos antes. Lá, Espíndola apresentou-lhe um pequeno baú pertencente a Augusto. O subdelegado fez a lista do seu conteúdo: um par de sapatos, três pares de calças pretas, um paletó de pano da mesma cor, uma jaqueta branca, um par de calças de brim branco, além de duas camisas da mesma cor, três pares de calças velhas, uma gravata de cetim preto, um chapéu de palha de chiles, dois chapéus de pelo preto, um barrete de algodão colorido e um chapéu de molas.

Seguindo os procedimentos judiciais devidos para o seu inventário post-mortem, o juiz de órfãos apontou um depositário para os bens de Augusto, tornou pública a convocação para a habilitação dos herdeiros e devedores, e deu procedimento à avaliaçáo dos bens do morto.

Dentro de um prazo de três meses, o juiz cumpriu as exigências formais, começando pela convocação do tenente-coronel Espíndola para que prestasse depoimento. Através de Espíndola acabamos sabendo que Augusto lhe havia sido distribuído por ordem do governador da Província de Alagoas em 1850, onde servia como capitão, e que Augusto era parte de um "bando" mais amplo, de "cento e setenta (outros africanos) que, na qualidade de contrabando, foi apanhado no desembarque pela força do governo". ${ }^{4}$ Capturado como mercadoria ilegalmente contrabandeada e, graças à legislação pela qual as autoridades brasileiras tentavam (muito a contragosto) coibir o tráfico tornado ilegal após a lei de 1831, "liberado" para tornar-se um "africano livre", Augusto teve seus serviços assinalados a um cidadão privado que os teria arrematado em praça pública. Quando Espíndola fora transferido de Alagoas a uma nova posição no Desterro, o africano o havia acompanhado.

Assim como para muitos na mesma situação, sua "liberdade" era cheia de ambiguidades práticas e legais. De acordo com Espíndola, Augusto estava sob "sua direção e abaixo do seu governo", mas "morava e assistia fora, e que somente vinha dormir em sua casa, sendo que nela nunca teve senão uma esteira e um travesseiro". Ali passava as noites e também conseguia uma refeição ocasional. Augusto estava, entretanto, acostumado a viver e trabalhar por si, e cumpria suas obrigaçóes com o homem que costumava chamar de "senhor" através do pagamento de um "jornal” em dinheiro, tirado das suas próprias atividades como marinheiro. Quando o juiz lhe perguntou sobre o dinheiro que Augusto poderia ter deixado, Espíndola lembrou de ter ouvido "da voz pública” que o africano poderia ter deixado mesmo alguns contos de réis, pois Augusto trabalhava no "costado de uma polaca", 5 sendo o "preto

\footnotetext{
${ }^{4}$ Ver também: "Rellação dos Africanos pretos livres, pessôas particulares que arrematarão seus serviços, e dos Estabelecimentos publicos a que forão destinados de ordem do Exmo. Prezidente desta Provincia nesta cidade no anno de 1850". Arquivo Público de Alagoas. Caixa: Curador de Africanos, apud SILVA, Moisés et alli. Relatório final da Pesquisa - Fontes para a História da Escravidão em Alagoas. Universidade Estadual de Alagoas, 2010, p. 241 (não publicado).

5 "Polaca" ou "polacra" denominava uma embarcação a vela e a remo, de três mastros utilizada para o transporte de mercadorias no Mediterrâneo e no Levante (ver SILVA, Antonio de Moraes. Diccionario da lingua portugueza, v. 2, 2. ed. Lisboa: Typographia Lacerdina, 1813, p. 463). No caso, presumivelmente, trata-se de uma embarcação mercantil de três velas ainda em uso em meados do século XIX.
} 
de confiança para esses negócios de trabalhos" de um negociante local chamado Maximiano José de Magalhães Souza, que lhe pagava um salário mensal de $60 \$ 000$ réis há perto de dois anos, e que esta não era a única fonte de renda de Augusto.

De acordo com Espíndola, Augusto não havia deixado nada sob seus cuidados, e acrescentava: "tanto mais quando é sabido e cousa natural que os escravos sempre se acanham com os seus senhores e somente com quem [estão] mais em confiança e familiaridade é que se [abrem] e correspondem-se". Claramente considerando Augusto não muito diferente de um escravo nesses assuntos, o tenente-coronel disse conhecer muito pouco da vida do seu antigo tutelado, sugerindo o nome de outros conhecidos do africano, de quem o juiz de órfăos poderia extrair outras informaçôes.

Os testemunhos que se seguiram à investigação dão-nos uma imagem mais clara daquele jovem que vivia a ambiguidade prática e legal da sua condição de um trabalhador tutelado e africano livre. As testemunhas mobilizaram uma série de palavras para descrever o comportamento de Augusto: Chamado a depor, o ferreiro Daniel Antônio de Silva Simas afirmou que Augusto tinha a reputação de ser "preto muito trabalhador, diligente, ativo e econômico". Espíndola, por sua vez, afirmava que a "voz pública" considerava que o preto era "econômico, poupador e fiscalizador do que era seu".

Seu empregador, Maximiano Souza, proprietário de barcos e comerciante ativo na praça do porto do Desterro, foi ainda mais enfático. Declarou que:

o preto era tão diligente, dedicado ao trabalho e econômico que não perdia tempo trabalhando sempre e de tudo fazendo dinheiro, sendo que em despesa quase nenhuma gastava, [pois] além dele respondente dar-lhe comida e vestir como geralmente é sabido, ocorre que suprimentos iguais recebia ele pelas suas boas maneiras e qualidades dos comandantes dos navios em que trabalhava, e que a sua economia era tal que muitas vezes até para comprar cigarros ele pedia dinheiro [emprestado], de sorte que necessariamente tinha outro ganho independente do que the dava ele respondente. Perguntado se seria verdade que o preto Africano Augusto pagasse ao tenente-coronel Espíndola com ganho de dois cruzados por dia? Respondeu que assim lhe disse o preto, assim disseram alguns outros seus companheiros, e assim o acredita ele respondente, por que o preto Augusto era muito fiel, sincero e verdadeiro. ${ }^{6}$

\footnotetext{
6 "Inventário de Augusto Africano Livre", op. cit. fls. 12v-13.
} 
Do testemunho de Maximiano de Souza descobrimos algo sobre a remuneração de Augusto, que recebia, de acordo com seus trabalhos, entre cinco patacas ${ }^{7}$ e $2 \$ 000$ réis por dia. Arranjos similares ele provavelmente tinha com outros patrôes e do dinheiro recebido pagava Espíndola - a quem devia "jornais" - uma compensação de dois cruzados $(\$ 800)$ por dia.

As derradeiras informaçóes que temos sobre a vida de Augusto foram dadas por seu camarada, o liberto africano Joaquim, que com ele e outros quatro dividia o aluguel de uma casinhola na rua da Palma, pagando cada um quatro patacas e seis vinténs por mês (1\$400). Joaquim também assegurou ao juiz que Augusto não havia deixado escondido nenhum outro dinheiro além daquele encontrado e, perguntado sobre as origens de Augusto, respondeu: "que pelas marcas e a língua, sabe que era Preto Mina", indicando suas origens na costa ocidental da África.

A investigação sobre Augusto e seus pertences não achou evidência de nenhum outro dinheiro deixado para trás. Em alguns dias, o juiz de órfãos mandou que se arrematasse os poucos bens em praça pública e deu por encerrado o caso. Sem ter deixado herdeiros, o saldo remanescente das posses de Augusto, incluindo suas economias, foi incorporado aos cofres públicos.

\section{A volta do big picture}

Tal como foram apresentados até aqui, os eventos que definiram o que sabemos sobre a breve vida de Augusto Mina parecem remeter, uma vez mais, para a tensão — tão presente na consciência historiográfica das últimas décadas — entre a riqueza singular da biografia individual e as estruturas sociais que definem seus limites. A excepcionalidade da sua trajetória interrompida aparece em contrapeso à realidade cotidiana e opressiva de um sistema legal de trabalho tão marcado pela exploração que mal se distinguia da própria escravidão. Se, por um lado, a sua história é marcada pela singularidade, tão local e circunscrita, das suas vicissitudes pessoais, não há dúvida que a vida de Augusto pertence também à ampla história das conexôes transcontinentais. Processos históricos que atravessaram o globo deram o enquadramento da sua vida: a longa história do trabalho escravo; o tráfico africano e a sua abolição no Atlântico no século XIX, a expansão do alcance do comércio internacional e a difusão das ideologias do trabalho livre; do mesmo modo a invenção de novas formas de administraçáo de mão de obra no mundo colonial como um todo.

A história de Augusto parece apontar, então, para uma encruzilhada de pesquisa. A pergunta que se impóe diante de histórias como a dele é sobre nossa capacidade de navegar

\footnotetext{
7 "Pataca", "cruzado" e "vintém" eram denominaçôes de moedas circulantes de metal no Brasil do século XIX. Um "cruzado" correspondia a $\$ 400$ (quatrocentos réis); "patacas" era como eram chamadas as moedas de prata de $\$ 320$ (trezentos e vinte réis); “vinténs" eram moedas de cobre de 20 réis.
} 
entre esses dois polos aparentemente inconciliáveis, isto é de articular a análise da vida individual com os grandes processos sociais mais amplos. Neste artigo, gostaria de revisitar essa discussão - teórica e historiográfica — à luz dos recentes debates historiográficos sobre a emergência de uma "história global". Para isso, pretendo conectar a história de Augusto à discussão corrente sobre o tema da história global no campo dos estudos sobre o trabalho, explorando as tensôes entre a demanda por um big picture — o contexto maior - e a análise circunscrita, aproximada, de casos singulares como o dele. Essas questôes serão abordadas inicialmente através de uma discussão dos sentidos atribuídos a uma perspectiva "global" na historiografia recente, assim como do exame da sua suposta oposição a uma perspectiva que poderíamos chamar "micro-histórica". Ao fim, voltaremos a Augusto, seus pertences e seu destino, tentando pensar sobre o lugar que sua história poderia ocupar em uma discussão mais ampla sobre a história do trabalho.

O argumento contemporâneo sobre a emergência da "história global" aponta para a retomada do debate sobre a centralidade de uma abordagem sistêmica — ou "macro" — da realidade social, política e econômica no campo do raciocínio histórico. ${ }^{8}$

Este é um debate que parecia ter sido definitivamente perdido pela velha história social triunfante até o início dos anos 1970, e vencido pelas várias vertentes historiográficas que, desde então, chamaram a atenção para os limites de uma abordagem que, enfatizando o peso das estruturas econômicas e sociais, negligenciava o alcance da ação de grupos e indivíduos sobre essas mesmas estruturas. Esta crítica também mostrava como, ignorando o peso relativo de outras dimensôes da realidade, da cultura e da experiência humana que não se encaixavam facilmente em sua hierarquia de importâncias predefinida, a história social tal

\footnotetext{
${ }^{8}$ As indicações desta retomada são muitas, como atestam as referências citadas nas notas deste artigo, entre muitas outras. Entre as críticas recentes a abordagens percebidas como excessivamente centradas em um recorte espacial, temporal e temático circunscrito, destacam-se: WILDER, Gary. From Optic to Topic: The Foreclosure Effect of Historiographic Turns. American Historical Review, v. 117, n. 3, p. 723-745, 2012; ARMITAGE, David; GULDI, Jo. The History Manifesto. Cambridge, MA: Cambridge University Press, 2014. Em seu livro, Armitage e Guldi, em nome da relevância da história para lidar com as questóes fundamentais da contemporaneidade - como as mudanças climáticas e a persistência da desigualdade em escala global —, fazem uma defesa enfática de uma perspectiva histórica que se volte para os grandes processos e para a longa duração. Importante notar, entretanto, que essas críticas não deixam de encontrar também respostas incisivas. Ver: ASLANIAN, Sebouh David et al. AHR Conversation How Size Matters: The Question of Scale in History. The American Historical Review, v. 118, n. 5, p. 1431-1472, 2013; e o fórum publicado nas páginas da American Historical Review sobre o livro de Armitage e Guldi, em 2015: COHEN, Deborah; Peter Mandler. The history manifesto: A critique. The American Historical Review, v. 120, n. 2, p. 530-542, 2015; e ARMITAGE, David; Jo Guldi. The History Manifesto: A Reply to Deborah Cohen and Peter Mandler. The American Historical Review, v. 120, n. 2, p. 543-554, 2015.
} 
como era praticada então havia se demonstrado incapaz de cumprir sua promessa de investigar e compreender a natureza das transformaçóes históricas. ${ }^{9}$

Diante deste quadro, vale a pena chamar a atenção sobre as diferenças e semelhanças entre o debate historiográfico que acabei de descrever e (re)emergência do tema da "história global" nos últimos anos.

Há certamente muitos pontos em comum entre a nova perspectiva "global" e a abordagem totalizante que estava presente entre as preocupaçóes centrais da história social e econômica mais importante até pelo menos o início dos anos 1970 — das quais podemos citar, entre outros, o trabalho de Fernand Braudel ou de Charles Tilly. ${ }^{10}$

Mas o contexto político e intelectual onde a nova inflexão em direção ao "global" vem tomando lugar é também muito importante. Em primeiro lugar - e em contraste com o momento anterior - o interesse corrente por um recorte mais amplo se desenvolve em um ambiente intelectual que alguns comentadores percebem como saturado pela atenção a contextos desconectados, temas dispersos, sujeitos sociais fragmentados e histórias locais. Em oposição a essa "história em migalhas", ${ }^{11}$ uma atitude intelectual que enfatiza as conexóes e adota uma perspectiva de larga escala apresenta-se como um antídoto aos excessos de uma história social e cultural que parece ter abandonado qualquer ambição de abordar de modo sintético e amplo a realidade social no tempo. Não há dúvida que essa síntese da historiografia das últimas décadas peca pela simplificação, mas é possível concordar com ela ao menos em um ponto: o recente apelo e interesse por um enquadramento histórico e geográfico mais amplo dos problemas de pesquisa dos historiadores está ancorado em um conjunto de questôes que estiveram ausentes — ou, no mínimo, pouco representadas - no centro do palco do debate histórico por um longo tempo. ${ }^{12}$

Não menos importante para o interesse corrente sobre o big picture está a emergência do conceito de "globalização" para descrever o momento presente de expansão dos mercados transnacionais e o desenvolvimento de novas formas de interdependência no capitalismo moderno. Mesmo severos críticos da "globalização" — seja do fenômeno em si, seja do conceito analítico - concordam que há algo a aprender com a ideia de levar em consideração conexôes mais amplas. Como afirmou Frederick Cooper: "Por trás da moda da globalização

\footnotetext{
${ }^{9}$ Para uma visita inteligente a esse debate historiográfico, ver ELEY, Geoff. A Crooked Line from Cultural History to the History of Society. Ann Arbor: Michigan University Press, 2005.

${ }^{10}$ RIELLO, Giorgio. La globalisation de l'histoire globale: une question disputée. Revue d'histoire moderne et contemporaine. 2007/5, n. 54-4bis, p. 23-33, 2007.

${ }^{11}$ Para usarmos um termo cunhado por François Dosse e que circulou amplamente no debate historiográfico sobre os desenvolvimentos da história social francesa. Ver DOSSE, François. A história em migalhas. Dos annales à nova história. Campinas: Edunicamp/Ed. Ensaio, 1992.

${ }^{12}$ Vale notar que perspectivas como as de Braudel e Tilly não desaparecem do horizonte do debate histórico, mas se deslocam do seu centro tanto intelectual quanto institucional. O interesse por temas de longa duração e por uma abordagem sistêmica mantiveram sua vitalidade em contextos acadêmicos específicos que nunca deixaram de ter importância, como o Fernand Braudel Center for the Study of Economies, Historical Systems, and Civilizations, na Binghamton University.
} 
está uma busca importante pela compreensão da interconectividade das diferentes partes do mundo, pela explicação dos novos mecanismos que dão forma ao movimento dos capitais, das pessoas e da cultura, e pela investigação sobre as instituiçóes capazes de regular tais movimentos transnacionais". ${ }^{13}$ Essas palavras são de um interesse particular, porque foram escritas por um historiador do trabalho cujo campo de estudo é a África colonial e pós-colonial, e fazem parte de uma crítica aguda à pretensão do "global" de se tornar a nova moda dos estudos históricos. Cooper critica a globalização desde a perspectiva de alguém que passou sua carreira estudando um espaço geopolítico que sofreu no passado, assim como hoje, o impacto dessas conexôes transcontinentais com particular severidade.

As observaçóes de Cooper também devem ser lidas dentro do contexto do interesse contemporâneo renovado por uma perspectiva global nos estudos sobre o trabalho, que é crítica à abordagem eurocêntrica e imperialista que caracterizou as versóes anteriores desse interesse pelo "global". A expansão temática e conceitual que a história do trabalho vem experimentando hoje, incorporando dimensōes que foram negligenciadas pelos estudos tradicionais sobre o trabalho, como os mundos do trabalho informal e "não livre", é fortemente inspirada pelo compromisso em olhar para os processos sociais transnacionais e interconectados, escapando do ponto de vista que focava exclusivamente o Atlântico Norte. ${ }^{14}$

Ainda assim, mesmo uma história do trabalho revigorada pode tirar proveito do alerta de Cooper de que o uso do "global" para definir o escopo de qualquer processo de interconexão pode levar a novos mal-entendidos, sobretudo ao sacrificar a "profundidade histórica" implicada no uso dos conceitos : "É salutar", escreve Cooper, "distanciar-se de quaisquer tendências que possam levar a analisar processos sociais, econômicos, políticos e culturais como se eles tivessem lugar em compartimentos nacionais ou continentais; mas ao adotar uma linguagem que implique a completa ausência de compartimentos, com a exceção do planetário, arrisca-se a definir os problemas de modo enganoso." 15

Cautela intelectual e um ceticismo saudável diante das modas historiográficas são sempre bem-vindos, uma vez que sejamos capazes de distinguir entre as boas perguntas e as más respostas: Se a terminologia pode ser inadequada ou enganosa, como pode-se facilmente incorrer com o "global" ou a "globalização" usados como conceitos analíticos trans-históricos, as questôes que esses conceitos estão tentando capturar e explicar não são.

Considerando o propósito principal deste artigo, de discutir as congruências possíveis entre as perspectivas global e microanalítica tomando o amplo campo da história do trabalho como ponto de partida privilegiado, há ainda algumas questôes por tratar. A primeira delas trata do significado substantivo que uma abordagem "global" pode ter no mundo real

\footnotetext{
${ }^{13}$ COOPER, Frederick. What Is the Concept of Globalization Good for? An African Historian's Perspective. African Affairs, v. 100, n. 399, p. 212-13, 2001.

${ }^{14}$ VAN DER LINDEN, Marcel. Trabalhadores do mundo: ensaios para uma história global do trabalho. Campinas: Edunicamp, 2013, p. 9.

${ }^{15}$ COOPER, Frederick, op. cit., p. 190.
} 
da pesquisa histórica e, portanto, sobre o conteúdo historiográfico do termo. A segunda, considerando a tensão lógica entre os termos "global" e "micro", é a pergunta sobre qual poderia ser o terreno onde essas duas perspectivas poderiam aprender uma da outra?

\section{História global}

O termo "história global" é relativamente novo. Uma revista acadêmica exatamente com este título vem sendo publicada apenas desde 2006. "História mundial", outro termo que circula no mesmo contexto acadêmico e que sugere alguma analogia, é mais antigo, mas aponta para trabalhos com um interesse mais forte na história do colonialismo e do imperialismo na era moderna. ${ }^{16}$ De todo modo, uma "história global" como um campo de interesses, distinto da necessária mas insuficiente história dos impérios e do imperialismo, emergiu muito recentemente. Podemos mesmo dizer que o termo ainda é uma caixa ao qual foi adicionado um rótulo, mas cujo teor ainda está por ser efetivamente definido. A demarcaçáo dos seus conteúdos, métodos e limites (uma questão que não pode ser resolvida pela afirmação de que eles não existem) ainda está em disputa.

Estas questôes não são novas. Como lembrou David Armitage, o historiador francês Fernand Braudel, ao discutir o próprio escopo de seu estudo sobre o mar Mediterrâneo, "alertava que 'o Mediterrâneo histórico parece ser um conceito capaz de ser estendido infinitamente", e pensava em voz alta: "Mas quão distante no espaço estamos autorizados a ir?". ${ }^{17}$ Armitage, ele mesmo incentivador de uma perspectiva histórica "global", fazia as mesmas questôes sobre o oceano Atlântico, cuja história compartilha alguns dos mesmos desafios e ambiçôes similares de desafiar a sabedoria convencional de que as fronteiras dos estados-nação são os contextos naturais e autodelimitados da pesquisa histórica.

O campo da "história atlântica" nos dá, aliás, exemplos abundantes de tentativas mais ou menos bem-sucedidas de abordar conexóes e processos históricos trans-territoriais. ${ }^{18}$ Con-

\footnotetext{
${ }^{16}$ The Journal of Global History, editado no âmbito da London School of Economics, é publicado pela Cambridge University Press desde 2006. Journal of World History é publicado pela World History Association desde 1990. "World History" é um termo preferido por outros estudiosos, como: CURTIN, Philip. CrossCultural Trade in World History. Cambridge: Cambridge University Press, 1984, e BENTON, Lauren. Law and Colonial Cultures: Legal Regimes in World History, 1400-1900. Cambridge: Cambridge University Press, 2001. Vale também apontar aqui o periódico pioneiro publicado em Leipzig desde 1991: Comparativ. Zeitschrift für Globalgeschichte und Vergleichende Gesellschaftsforschung.

${ }^{17}$ Citado em ARMITAGE, David. Three Concepts of Atlantic History. In: ARMITAGE, D.; BRADDICK, M. J. (Org.). The British Atlantic World, 1500-1800. Nova York: Palgrave Macmillan, 2002, p. 26.

${ }^{18}$ Os elementos comuns entre as histórias globais e a história Atlântica foram apontados por Jean-Paul Zuniga. L'Histoire Impériale à l'heure de l'‘histoire globale'. Une perspective atlantique. Revue d'histoire moderne et contemporaine. n. 54-4bis, p. 57, 2007/5. É preciso apontar, entretanto, que o debate sobre a chamada "História Atlântica" não se resume às referências e discussóes que eu apenas aponto de passagem neste artigo. Para referências que apontam para as diversidades de perspectiva dentro da História Atlânti-
} 
siderando o papel central desempenhado pelo comércio de escravos e o trabalho cativo na construção do mundo atlântico, um tópico fundamental de qualquer abordagem da história do trabalho desde uma perspectiva global, não é de surpreender que a história da escravidão ocupe um papel crucial nessa área de investigação, ao menos nas últimas décadas. ${ }^{19} \mathrm{E}$, de fato, trabalhos que precocemente se engajaram no entendimento das "dinâmicas do tráfico de escravos e da abolição, a relação entre a escravidão e a industrialização, a Revolução Haitiana”, por historiadores como W. E. B. Dubois, C. L. R. James e Eric Williams, como mais uma vez relembra David Armitage, haviam "obvia e conscientemente" prestado atenção ao alcance Atlântico dos seus temas. ${ }^{20}$ Mais tarde, a mesma consciência sobre a impossibilidade de compreender realmente a escravidão sem reconhecer a importância central das conexôes e interdependências acabou por prevalecer entre os especialistas pesquisando a Europa e as Américas. Esse entendimento foi fundamental, por exemplo, para trabalhos tanto diversos quanto seminais, de historiadores como David Brion Davis ou Pierre Verger, cujos livros, publicados entre o fim dos anos 1960 e início dos 1970, tentaram, respectivamente, compreender o lugar da escravidáo no mundo intelectual e político do Atlântico Norte, e explorar as profundas conexões comerciais entre as costas brasileira e da África ocidental, no Atlântico Sul. ${ }^{21}$

Prestar atenção às relações intercontinentais nem sempre significa, entretanto, que todas as partes do mundo Atlântico receberam a mesma atenção. Com frequência, uma ênfase nas conexóes ao norte do Atlântico e as influências europeias acabaram por deixar na sombra um leque de intercâmbios mais dinâmico e diverso. ${ }^{22}$ Mesmo um livro que levanta um forte argumento sobre as consequências radicais de se levar seriamente em consideração a circulação de ideias e pessoas no Atlântico — A hidra de muitas cabeças, de Peter Linebaugh e Mar-

ca, ver: GREENE, Jack P.; Philip D. Morgan (Org.). Atlantic History. A critical appraisal. Oxford: Oxford University Press, 2009.

${ }^{19}$ Armitage sublinha, entretanto, que versōes anteriores da "História Atlântica" — isto é, das "correntes anti-isolacionistas na história dos Estados Unidos do século vinte", concentraram-se em discutir as conexôes entre os Estados Unidos e a Europa, prestando pouca ou nenhuma atenção ao "tráfico de escravos e à escravidão, e a África, os africanos, ou à raça como tema mais geral”, Cf. ARMITAGE, cit. 2002, p. 14. Ver também: GILROY, Paul. O Atlântico negro. Modernidade e dupla consciência. São Paulo/Rio de Janeiro: Ed. 34/Universidade Candido Mendes, 2001.

${ }^{20}$ Idem. Uma lista, ainda que breve e incompleta, de referências importantes sobre o debate em torno da História Atlântica não pode deixar de ter, além de outras citadas neste artigo: BAYLIN, Bernard. Atlantic History: Concept and Contours. Cambridge: Harvard University Press, 2005; GAMES, Alison; EGERTON, Douglas (Org.). The Atlantic World: A history, 1400-1888. Hoboken: Wiley-Blackwell, 2007; GREENE, Jack; MORGAN, Philip (Org.). Atlantic History: A Critical Appraisal. Nova York: Oxford University Press, 2008.

${ }^{21}$ DAVIS, David Brion. The Problem of Slavery in the Western Culture. Ithaca, NY: Cornell University Press, 1966; DAVIS, David Brion. The Problem of Slavery in the Age of Revolution. Ithaca, NY: Cornell University Press, 1975; VERGER, Pierre. Fluxo e refluxo do tráfico de escravos do Golfo do Benin e a Babia de Todos os Santos dos séculos XVII a XIX. Salvador: Corrupio, 1987 (originalmente publicado em francês em 1968).

${ }^{22}$ Ver, por exemplo, as observaçôes de LAW, Robin; MANN, Kristin. West Africa in the Atlantic Community: The Case of the Slave Coast. The William and Mary Quarterly, v. 56, n. 2, p. 307-334, 1999; e FERREIRA, Roquinaldo. Cross-Cultural Exchange in the Atlantic World: Angola and Brazil during the era of the slave trade. Nova York: Cambridge University Press, 2012. 
cus Rediker —, não conseguiu efetivamente ir além (ou abaixo) do Atlântico Norte na sua busca pela horda heterogênea da classe trabalhadora revolucionária multiétnica e oceânica. ${ }^{23}$

Desde a perspectiva do Atlântico Sul, entretanto, as muitas ligaçôes entre a África e a América estáo crescentemente se tornando mais importantes que as antigas (e mais bem estudadas) assimetrias e relaçôes de exploração entre as metrópoles e as colônias. Indo além do estudos dos "sistemas coloniais", essa historiografia está engajada no entendimento de como as pessoas das duas costas do oceano meridional tiveram participaçáo ativa na construção de uma complexa rede de transaçôes econômicas e políticas, bem como instituiçôes sociais e relações humanas no vasto espaço geopolítico do Atlântico moderno. ${ }^{24}$

\section{Encontrando o lugar para a redução da escala}

A maior parte dos trabalhos que enfocaram o amplo campo da "História Atlântica" poderia ser usada para exemplificar aquela perspectiva "sistêmica" defendida por David Brion Davis como o antídoto para a compartimentalizaçáo excessiva (e, poderíamos dizer, a perspectiva nacionalista) que ainda é a norma entre os estudos sobre a escravidão, tanto no hemisfério norte quanto no sul. ${ }^{25}$ Muito frequentemente, entretanto, a estratégia de pesquisa preferida pelos historiadores comprometidos em dar conteúdo a uma perspectiva atlântica é seguir as trajetórias transcontinentais de indivíduos de grande mobilidade. Neste contexto, e de modo significativo, muitos desses estudos lançaram seu foco sobre as vidas (muitas vezes excepcionais) de escravos e libertos. ${ }^{26}$

\footnotetext{
${ }^{23}$ LINEBAUGH, Peter; REDIKER, Marcus. A hidra de muitas cabeças. Marinheiros, escravos, plebeus e a história oculta do Atlântico revolucionário. São Paulo: Companhia das Letras, 2008. Uma observação semelhante pode ser feita sobre Paul Gilroy em $O$ Atlântico negro (op. cit.). Para uma perspectiva mais ampla (ou global) sobre a era das Revoluçóes, ver: ARMITAGE, David; SUBRAHMANYAM, Sanjay (Org.). The Age of Revolutions in Global Context, c. 1760-1840. Nova York: Palgrave Macmillan, 2010.

${ }^{24}$ Os exemplos são vários. Ver, entre outros: THORNTON, John. Africa and Africans in the Making of the Atlantic World, 1400-1800. Cambridge: Cambridge University Press, 1992; ALENCASTRO, Luís Felipe de. $O$ trato dos viventes. Formação do Brasil no Atlântico Sul, séculos XVI e XVII. São Paulo: Companhia das Letras, 2000; FLORENTINO, Manolo. Em costas negras. Uma história do tráfico de escravos entre a África e o Rio de Janeiro. São Paulo: Companhia das Letras, 1997; CURTO, José C.; LOVEJOY, Paul E. (Org.). Enslaving Connections: Changing Cultures of Africa and Brazil During the Era of Slavery. Amherst, NY: Humanity Books, 2003; COSTA E SILVA, Alberto da. Um rio chamado Atlântico: a África no Brasil e o Brasil na África. Rio de Janeiro: Nova Fronteira, 2011.

${ }^{25}$ DAVIS, David Brion. Looking at Slavery from Broader Perspectives. The American Historical Review, v. 105, n. 2, p. 452-466, abril 2000. Este artigo é parte de um Forum da American Historical Review, intitulado Crossing Slavery's Boundaries (atravessando as fronteiras da escravidão), publicado no mesmo número da AHR e contando ainda com a participação de Peter Kolchin, Rebecca J. Scott e Stanley L. Engerman.

${ }^{26}$ Os exemplos são vários, dos quais vale destacar: SPARKS, Randy J. The Two Princes of Calabar. An Eighteenth-Century Odissey. Cambridge: Harvard University Press, 2009; MAMIGONIAN, Beatriz G.; RACINE, Karen (Org.). The Human Tradition in the Black Atlantic, 1500-2000. Lanham, MD: Rowman \& Littlefield, 2009; MAMIGONIAN, Beatriz G. José Majolo e Francisco Moçambique, marinheiros das
} 
A combinação, e a eventual tensão, entre a pesquisa intensa sobre as vidas e trajetórias individuais e o esforço em considerar o fluxo intercontinental de pessoas, bens e cultura levanta, obviamente, um importante conjunto de questôes teóricas e historiográficas. Nesse sentido, a análise crítica feita por Rebecca Scott do argumento de Brion Davis é reveladora: Ela lembra as dimensóes "potencialmente problemáticas" de uma história cuja ênfase recai sobre uma abordagem ampla e sistêmica da escravidão: o risco de apenas "prestar atenção à história dos atores que operam em um âmbito sistêmico amplo, como banqueiros, comerciantes e plantadores", apagando do quadro aquilo que ela considera "um dos mais duráveis discernimentos conseguidos pelos estudos da escravidão nas últimas décadas", isto é: “a interação, frequentemente muito local, entre as açôes dos escravos, das pessoas livres de cor, os senhores, os lavradores sem escravos, e o estado". Em uma palavra: a agência (agency), um termo e ideia "um pouco batido", mas ainda bastante útil. ${ }^{27}$

O próprio trabalho de Scott exemplifica esse impulso de combinar uma perspectiva "macro" e uma abordagem microanalítica. Seu último livro, escrito em coautoria com Jean Hébrard, ${ }^{28}$ coloca sob foco os quase duzentos anos de história da família de Rosalie, uma mulher escravizada na Senegambia, através da Revolução Haitiana, a guerra civil norte-americana e a reconstrução, indo até a Segunda Guerra Mundial, discutindo a emergência e disseminação da ideia de "direitos públicos" no Atlântico.

Essa "micro-história em movimento" - termo com que Scott descreve o seu trabalho — reenquadra em uma perspectiva atlântica e mesmo global algumas das mesmas questôes que fizeram o debate sobre a "micro-história" relevante quando foi inicialmente articulado: a desconfiança com relação aos modelos gerais de explicação que acabam por obscurecer a importância das experiências individuais e as ações de atores sociais menos visíveis, assim como os elementos contraditórios que não se conformam facilmente com o "quadro geral" (big picture).

E, de fato, leituras superficiais do termo, de resto ambíguo, "micro" deram lugar à ideia convencional de que a micro-história prestaria atenção apenas aos cenários locais, aos indivíduos e eventos anônimos, e em objetos históricos fragmentados. Ao contrário, entretanto, se considerarmos os principais argumentos que inspiraram os trabalhos dos micro-historiadores, ou ao menos aqueles mais teoricamente conscientes entre eles, podemos encontrar um progra-

rotas atlânticas: notas sobre a reconstituição de trajetórias da era da Abolição. Topoi, v. 11, n. 20, p. 75-91, jan.-jun. 2010; REIS, João José; GOMES, Flávio dos Santos; CARVALHO, Marcus J. M. de. O alufá Rufino: tráfico, escravidão e liberdade no Atlântico negro. São Paulo: Companhia das Letras, 2010; COSTA E SILVA, Alberto da. Félix de Souza, mercador de escravos. Rio de Janeiro: Nova Fronteira, 2011; SWEET, James H. Domingos Álvares, African Healing, and the Intellectual History of the Atlantic World. Chapel Hill: The University of North Carolina Press, 2011; LINDSAY, Lisa A.; SWEET, John W. (Org.). Biography and the Black Atlantic. Philadelphia: University of Pennsylvania Press, 2014.

${ }^{27}$ SCOTT, Rebecca J. Small-Scale Dynamics of Larger-Scale Processes. The American Historical Review, v. 105, n. 2, abril 2000, p. 473.

${ }^{28}$ SCOTT, Rebecca J.; HÉBRARD, Jean. Freedom Papers: An Atlantic Odyssey in the Age of Emancipation. Cambridge: Harvard University Press, 2012. 
ma de pesquisa que compreendia muito claramente a necessidade de integrar as singularidades da realidade histórica com os processos sociais de grande fôlego e longo alcance. ${ }^{29}$

Ao menos duas outras ideias que estavam presentes no projeto micro-histórico também são relevantes neste contexto: primeiro, a firme convicção de que uma redução radical da escala de observação poderia produzir resultados relevantes na análise de qualquer problema histórico, não importando sua dimensão ou escopo. Como consequência, os micro-historiadores tinham a ambição de que os grandes modelos explicativos poderiam ser repensados, corrigidos ou mesmo desafiados pela observação intensiva de casos particulares, trajetórias individuais e de grupo, e aspectos da realidade histórica que seriam de outro modo considerados estatisticamente irrelevantes e intelectualmente negligenciáveis. Em segundo lugar, a micro-história também foi importante para o reexame da ideia de "contexto" como um modelo geral e um enquadramento predefinido onde cada problema histórico encontra seu lugar natural. Ao contrário, de acordo com a micro-história, a análise crítica do "contexto" — não apenas a avaliação da sua pertinência, mas também sua definição e construção — deveria ser uma parte integral da análise histórica. Mesmo a imagem de um "jogo de escalas" - a variação controlada das diferentes escalas de observação — implicava exatamente a defesa dessa dimensão experimental na construção dos contextos. ${ }^{30} \mathrm{~A}$ micro-história, portanto, não se construiu em oposição a uma abordagem do "grande quadro" (big picture), mas antes como um modo de evitar considerar o "grande quadro" como uma realidade preestabelecida, cujos contornos seriam dados de antemão e utilizada sem exame. ${ }^{31}$

Marcel Van der Linden, um dos primeiros e mais convictos fomentadores de uma perspectiva global para os estudos históricos sobre o trabalho, ${ }^{32}$ insistiu repetidamente que uma

\footnotetext{
${ }^{29}$ Ver, por exemplo: REVEL, Jacques (Org.). Jogos de escalas. A experiência da microanálise. Rio de Janeiro: Editora da Fundaçáo Getulio Vargas, 1998; e (talvez mais claramente) GINZBURG, Carlo. Latitudes, escravos e a Bíblia: um experimento em micro-história, Art Cultura, v. 9, n. 15, p. 85-98, jul.-dez. 2007. Sobre as origens da micro-história italiana e suas ramificaçóes, ver: LIMA, Henrique Espada. A micro-história italiana: escalas, indícios e singularidades. Rio de Janeiro: Civilização Brasileira, 2006. Para uma discussão atualizada sobre as relaçóes entre a micro-história italiana e a história global, ver TRIVELATTO, Francesca. Is There a Future of Italian Micro-History in the Age of Global History?, California Italian Studies, v. 2, n. 1, 2011. Disponível em: <http://escholarship.org/uc/item/0z94n9hq>. Acesso em: 21 jan. 2015. Para uma crítica incisiva à "micro-história" (entendida em um sentido amplo), ver o artigo de WILDER, From Optic to Topic, op. cit.; e, mais amplamente, o livro de SEWELL, William H. Logics of History: Social Theory and Social Transformation. Chicago: Chicago University Press, 2005.

${ }^{30}$ Jacques Revel e Bernard Lepetit, em especial, utilizavam esta imagem em suas discussóes sobre a micro-história: ver REVEL, Jogos de escalas (op. cit.) e a contribuição de Lepetit no mesmo volume.

${ }^{31}$ Nesse sentido, importantes as considerações que retomam essa discussão em: DOUKI, Caroline; MINARD, Philippe. Histoire globale, histoires connectées: un changement d'échelle historiographique? Introduction. Revue d'histoire moderne et contemporaine, n. 54-4bis, p. 7-21, 2007/5. Ver também PUTNAM, Lara, To Study the Fragments/Whole: Microhistory and the Atlantic World. Journal of Social History, v. 39, n. 3, p. 615-630, 2006.

${ }^{32}$ E, com Jan Lucassen, criador do termo "Global Labor History" (GLH) em uma brochura que lançou o projeto: VAN DER LINDEN, Marcel; LUCASSEN, Jan. Prolegomena for a Global Labour History. Amsterdan: International Institute of Social History, 1999.
} 
"história global" não deveria ser compreendida nem como uma teoria para explicar "a ordem mundial capitalista”, nem como uma história da globalização. ${ }^{33}$ De acordo com ele, a história global do trabalho "não precisa ser feita apenas na grande escala; ela pode incluir também a micro-história”. Seria assim possível escrever uma "história global de um lugarejo, de um lugar de trabalho, ou de uma família” ${ }^{34}$

No argumento de Van der Linden, a história global do trabalho é um tipo de experimento intelectual que convida os historiadores a reconsiderarem os contextos mais amplos onde escrevemos nossas histórias, tentando prestar atenção nas dimensões comparativas de nossos temas e, de modo mais importante, nas conexôes e entrelaçamentos que estão silenciosamente presentes em qualquer pesquisa histórica. A dimensão experimental da história global do trabalho nesse sentido corresponde de modo muito próximo ao mesmo impulso presente na abordagem micro-histórica desde os seus princípios.

A despeito do fato de que, como corretamente aponta Van der Linden, os historiadores do trabalho sempre tiveram alguma consciência das dimensóes transnacionais do seu campo de pesquisa (como quando tratavam da história das migraçóes, ou na difusão das ideias políticas em escala transnacional), também é verdade que tanto o "nacionalismo metodológico" da historiografia mais tradicional quanto o enquadramento intelectual "eurocêntrico", que foi a sua maior influência, acabaram por prevenir o desenvolvimento de um sentido mais agudo de suas dimensões "globais". 35

Participando das profundas transformações do escopo da história social nas últimas décadas, com sua nova atenção sobre a pluralidade das questóes e dos atores sociais, a crítica ao eurocentrismo que caracterizou as teorias pós-coloniais, e a consequente atenção renovada às tradições historiográficas e a pesquisa que se produz fora dos países do Norte Atlântico, a história do trabalho começou a expandir e redefinir alguns dos seus principais conceitos e concepçôes. Os estudos sobre o trabalho e os trabalhadores finalmente foram capazes de ir além da atenção sobre trabalhador industrial, sindicalizado, jovem, usualmente branco, para começar a também reconhecer a centralidade das questóes sobre o gênero e a sexualidade, o trabalho doméstico e informal, ou as tensões e limites entre o trabalho "livre" ou "não livre" (escravo, compulsório e outros).

Tanto a micro-história quanto a história global (e outros campos relacionados, como as histórias conectadas e transnacionais) e suas várias vertentes podem ser vistas assim tanto

\footnotetext{
${ }^{33}$ VAN DER LINDEN, Marcel. The Promise and Challenges of Global Labor History. International Labor and Working Class History, v. 82, p. 57-76, outono de 2012.

${ }^{34}$ VAN DER LINDEN, Marcel. The Promise and Challenges of Global Labor History, op. cit., p. 7. Ver também a introdução a: VAN DER LINDEN, Marcel; MOHAPATRA, Prabhu (Org.). Labour Matters: towards global histories. New Delhi: Tulika Books, 2009.

${ }^{35} \mathrm{O}$ argumento de Van der Linden está desenvolvido nos textos citados de sua autoria. Para uma discussão anterior sobre o "nacionalismo metodológico" e sua definição, ver: WIMMER, Andreas; SCHILLER, Nina G. Methodological nationalism and beyond: nation-state building, migration and the social sciences, Global Networks, v. 2, n. 4, p. 301-334, 2002.
} 
como consequências quanto protagonistas dessas novas práticas de pesquisa e escrita da história, com as quais estamos hoje inteiramente comprometidos. Elas correspondem ao impulso necessário de redefinir os contextos relevantes e as categorias analíticas nas quais escrevemos, entre outras, as histórias de homens e mulheres escravizados, trabalhadores forçados e engajados, empregados domésticos, "indetured servants", trabalhadores coolie, ou (por que não?) "africanos livres".

\section{Sobre as pequenas coisas e o grande quadro}

Agora podemos voltar ao caso que serviu até agora como a longa epígrafe deste artigo. Como a história de Augusto encontra lugar nas possíveis conexóes entre a micro-história e a história global do trabalho?

Podemos começar com a longa história do trabalho escravo: Augusto foi transportado para a costa brasileira por rotas tradicionais de intercâmbio de bens e mercadorias que a conectava às distantes margens da África, Europa e além. Antes dele, milhóes de jovens africanos, homens, mulheres e crianças, capturados nos conflitos internos e nas razias estimulados pelo mesmo comércio, foram escravizados e carregados para as Américas por mais de trezentos anos. O tráfico de escravos era em si mesmo uma empresa extraordinariamente lucrativa para aqueles que o promoviam. No Brasil e em outros lugares, africanos escravizados foram usados para cultivar produtos que eram amplamente consumidos em uma rede transoceânica de mercadorias.

Um novo impulso de escravização e o comércio lucrativo de seres humanos, que alguns autores chamaram de "segunda escravidão", ${ }^{36}$ começaram exatamente em paralelo ao momento em que a instituiçáo da escravidáo estava passando por uma transformaçáo sem precedentes dentro da opinião pública ocidental, tornando-se uma abominação pública e perdendo o suporte moral que havia permitido que ela fosse considerada apenas um fato (desagradável que fosse) da vida durante tanto tempo. ${ }^{37} \mathrm{~A}$ lenta mas notável difusão das ideias abolicionistas desde meados do século XVIII aconteceu em paralelo e estava conectada com o triunfo da economia de mercado e o capitalismo naquelas mesmas potências coloniais que mais haviam lucrado com o "infame comércio", com a Grã-Bretanha à frente. ${ }^{38}$ A atuação

\footnotetext{
${ }^{36}$ Especialmente: TOMICH, Dale W. Pelo prisma da escravidão. Trabalho, capital e economia mundial. São Paulo: Edusp, 2011, capítulo 3. Ver também: TOMICH, Dale W.; MARQUESE, Rafael de Bivar. O Vale do Paraíba escravista e a formaçáo do mercado mundial do café no século XIX. In: Keila Grinberg e Ricardo Salles (Orgs.). O Brasil Imperial, 1831-1870. v. 2. Rio de Janeiro: Civilização Brasileira, 2009, p. 339-74; MARQUESE, Rafael de Bivar; PARRON, Tâmis Peixoto. Internacional escravista: a política da segunda escravidáo. Topoi, v. 12, n. 23, p. 97-117, 2011.

${ }^{37}$ MILLER, Joseph. The Problem of Slavery as History: A Global Approach. New Haven: Yale University Press, 2009.

${ }^{38}$ Para uma discussão historiográfica sobre as relaçôes entre o capitalismo internacional e a escravidão no
} 
diplomática britânica contra o comércio de escravos desde o início do século XIX (com sua abolição no império britânico em 1807 e a pressão subsequente sobre as metrópoles satélites como Portugal e as novas naçôes independentes americanas para suprimi-lo) e as subsequentes açôes militares contra os navios envolvidos no tráfico tiveram ao menos duas fortes consequências. Em primeiro lugar, rearranjaram as rotas e a logística da trata de escravos. Em segundo, a campanha militar e política dos britânicos para acabar com o tráfico serviu como catalisadoras de uma reorganização dos sistemas de trabalho no Atlântico e no mundo colonial em geral.

A situação de Augusto como um "africano livre" reflete essas dinâmicas. Ele foi ilegalmente transportado para o Brasil, onde tratados internacionais e a lei local haviam tornado o comércio negreiro ilegal desde 1831. Capturado em $1850 \mathrm{em}$ uma daquelas raras ocasiôes em que aquela lei foi realmente colocada em prática, como resposta parcial à pressão britânica, Augusto foi colocado em uma nova categoria jurídica que foi criada pelas mesmas leis internacionais responsáveis pela abolição do tráfico no longo prazo. "Africano livre" era a versão brasileira de uma forma legal dispersa pelo Atlântico, inspirada pelos experimentos britânicos com o trabalho "livre" no início do século XIX, como a instituição da "Aprendizagem" (Apprenticeship) e os status dos Indentured Africans..$^{39}$ Essas modalidades de mão de obra iriam mais tarde combinar-se com outras formas de trabalho forçado e compulsório que se tornaram a base para a administração de mão de obra no mundo colonial estendido da África e da Ásia.

Essa invenção era tanto uma resposta ao novo desgosto com o trabalho escravo quanto uma categoria sócio-legal inventada para dar forma à ideia de "trabalho livre" em um modo que viria a ser eventualmente utilizado como modelo para responder à demanda crescente de trabalho barato e disponível em um mundo capitalista colonial em expansáo. Preso contra a sua vontade a uma forma de contrato de trabalho no qual entrou sem conhecer os termos ou condiçôes, Augusto, como um "africano livre", teria sua "remuneração" mantida sob os cuidados das autoridades governamentais para eventualmente vir a pagar o seu retorno à África (nunca acontecido).

Brasil, ver: MARQUESE, Rafael de Bivar. As desventuras de um conceito: capitalismo histórico e historiografia sobre a escravidão brasileira. Revista de História, n. 169, p. 223-253, 2013.

${ }^{39}$ Ver RUPPRECHT, Anita. 'When he gets among his Countrymen, they tell him that he is free': Slave Trade Abolition, Indentured Africans and a Royal Commission. Slavery \& Abolition, v. 33, n. 3, p. 435-455, 2012; e COGHE, Samuël. The Problem of Freedom in a Mid-Nineteenth-Century Slave Society: The Liberated Africans of the Anglo-Portuguese Mixed Comission in Luanda (1844-1870). Slavery \& Abolition, v. 33, n. 3, p. 479-500, 2012. Referências importantes aqui também são os trabalhos clássicos de SCHULER, Monica. "Alas, Alas, Kongo": A Social History of Indentured African Immigration into Jamaica, 1841-1865. Baltimore: Johns Hopkins University Press, 1980; e HOLT, Thomas, The Problem of Freedom: Race, Labor, and Politics in Jamaica and Britain, 1832-1938. Baltimore: Johns Hopkins University Press, 1991. Contribuiçóes mais recentes incluem: SAFELA, Babatunde. Emancipados Slave Societies in Brazil and Cuba. Trenton: African World Press, 2011. 
No Brasil, assim como em outras sociedades escravistas, escravizados e livres não eram apenas espectadores passivos de profundas transformaçôes econômicas, políticas e sociais ininteligíveis. Ao contrário, eles sabiam bem que a difusão de novas ideologias do trabalho livre, assim como noçóes correlatas de direitos e prerrogativas naturais, abriam novas possibilidades práticas para trazer suas condiçōes de vida e trabalho mais próximas de suas próprias expectativas sobre a liberdade. Escravizados ou libertos, disputaram os termos de sua liberdade nas cortes judiciais e em frente a outras autoridades civis. Mesmo "africanos livres" foram capazes de manipular a seu favor as ambiguidades de sua condição, de modo a enfrentar, e às vezes evitar, algumas das dimensôes mais desagradáveis do seu estatuto.

O modo como Augusto viveu e experimentou esses processos transcontinentais também foi afetado e mediado pelas dinâmicas locais do lugar para onde ele foi trazido. Desde o início do século XIX, o Brasil havia se tornado um dos principais produtores de açúcar e café, especialmente depois que a Revolução Haitiana fez a antiga colônia francesa de Santo Domingo perder o seu lugar como a mais lucrativa colônia das Américas. Essa foi a principal razáo pela qual, apesar da supressáo do tráfico atlântico legal de escravos, no mesmo período mais de 700 mil africanos foram ilegalmente introduzidos como escravos e foram amplamente utilizados nas plantaçóes de café do Sudeste. Em contraste, apenas cerca de 11 mil africanos foram resgatados do comércio ilegal ao longo da costa brasileira entre 1821 e 1856, entre eles Augusto..$^{40}$ Trabalhando como marinheiro, Augusto estava envolvido na infraestrutura das conexôes mercantis entre a costa brasileira e o resto do mundo. Desterro não era um porto comercial importante, ${ }^{41}$ mas era certamente parte de uma rede intrincada, onde tanto mercadorias como ideias circulavam, carregadas por homens e mulheres de diferentes etnicidades, participando da nova expansão das relaçóes econômicas no Atlântico e além.

Esses mesmos processos reverberavam nos objetos que foram encontrados na gaveta chaveada do banquinho de Augusto e em seu baú, começando com aquelas mesmas notas de dinheiro com as quais ele era usualmente pago: manufaturadas nas impressoras industriais de Perkins, Bacon and Petch, na cidade de Londres, e importadas da Inglaterra pela Casa

\footnotetext{
${ }^{40}$ Cf. MAMIGONIAN, To be a liberated African ..., op. cit., p. 6. Em Desterro, a presença de africanos-livres como Augusto foi rara. Um dos poucos casos documentados — que não poderei explorar neste texto — é encontrado também em 1861, quando a africana Rufina, de nação benguela, solicita ao Presidente da Província de Santa Catarina sua completa emancipação. Rufina foi "emancipada" no ano seguinte, após 16 anos de serviços, com cerca de 35 anos de idade. Ver: Emancipação. Rufina Africana Livre. Fundo (em processo de organização): Juizo de Órfäos da Cidade do Desterro, 1861 - Arquivo do Museu do Judiciário Catarinense (Florianópolis, SC).

${ }^{41}$ Sobre a economia do porto do Desterro faltam trabalhos recentes que deem conta das suas relaçóes com os circuitos comerciais de abastecimento no período que trata este artigo. A referência disponível continua sendo: HÜBENER, Laura Machado. O comércio da cidade do Desterro no século XIX. Florianópolis: Ed. UFSC, 1981. Mais recentemente, Fabiane Popinigis vem desenvolvendo pesquisas sobre o pequeno comércio na cidade do Desterro que podem ser utilizados como referência complementar: ver POPINIGIS, Fabiane. Aos pés dos pretos e pretas quitandeiras: experiências de trabalho e estratégias de vida em torno do primeiro mercado público do Desterro, 1840-1890. Afro-Ásia, n. 46, p. 193-226, 2012.
} 
da Moeda brasileira desde $1835,{ }^{42}$ elas eram um elo em uma cadeia de trocas econômicas assimétricas e dependências transnacionais em ampla escala.

Finalmente, a história de Augusto era formatada também pelo modo pelo qual ele foi capaz de navegar e encontrar seu caminho pelos interstícios do mundo de obrigaçóes e sujeições no qual vivia.

Assim, se o conjunto de notas de papel moeda circulando no porto do Desterro era o indicador de uma crescente monetarização das relaçóes de trabalho e a constituição de um mercado de trabalho mesmo entre jornaleiros e trabalhadores braçais como Augusto, ele também poderia estar relacionado com outras atividades que o africano desenvolvia no porto: não apenas como marinheiro mas, muito provavelmente, como alguém que acabou por se envolver no recrutamento e na administraçáo da máo de obra de outros homens, escravizados e libertos, Africanos como ele, como sua reputação de "homem de confiança" poderia sugerir. ${ }^{43}$

O dinheiro de Augusto, incluindo as moedas de ouro e prata de maior valor (dinheiro que dificilmente teria sido usado para pagar um trabalhador braçal), nos fala de outros circuitos monetários que ele pode ter sido capaz de acessar. Essas moedas poderiam ser evidência de que ele talvez até mesmo conseguisse operar no mercado informal de créditos que existia em uma sociedade onde instituiçôes financeiras formais (como bancos e outros) ainda estavam se desenvolvendo. ${ }^{44} \mathrm{~A}$ participação nesse mercado de crédito informal expandia os recursos que os escravos tinham a sua disposição para negociar por sua liberdade. A habilidade de Augusto em adquirir uma boa reputaçáo tanto com os comerciantes brancos quanto com seus companheiros africanos teria certamente incrementado sua capacidade de fazer parte nesse negócio, que não usava apenas o dinheiro como moeda corrente, mas também a confiança e a reputação reconhecida pela "voz pública".

Mantendo um montante considerável de dinheiro sob o mesmo telhado que compartilhava com outros africanos, em vez de buscar a assistência de um dos patronos brancos com quem ele parecia ter boas relaçóes, Augusto nos sugere um relacionamento marcado pela confiança mútua e a camaradagem entre ele e seus pares. As relaçóes horizontais entre esses homens atravessavam as linhas divisórias de status, envolvendo tanto escravos como libertos. A escolha aparente de Augusto de tratar esses homens com "confiança e familiaridade" um privilégio que o capitão Espíndola perspicazmente percebeu que não tinha — revela um

\footnotetext{
${ }^{42}$ Sobre a companhia e a sua produção de papel-moeda para clientes internacionais, ver: HEWIT, V. (Org.). The Banker's Art: studies in Paper Money. Londres: British Museum Press, 1995.

${ }^{43} \mathrm{Um}$ indicador disso está no valor das notas e moedas de menor valor deixadas por Augusto: 20 moedas de quinhentos réis, 17 notas de dois mil-réis, e duzentas e seis notas de mil réis, entre outras. São valores que poderiam facilmente ter sido usados para o pagamento de jornais e outras remuneraçôes de pequeno porte, compatíveis com a contratação ou subcontratação da mão de obra flutuante do porto.

${ }^{44}$ Sobre as operações de crédito informal no Brasil do século XIX, ver as observaçôes de Zephyr Frank no seu: Entre ricos e pobres: O mundo de Antonio José Dutra no Rio de Janeiro Oitocentista. São Paulo/Belo Horizonte: Annablume/PPGH-UFMG, 2012.
} 
mundo de solidariedade social e interesses compartilhados que também eram uma parte fundamental da sua vida.

Se Augusto estava consciente da natureza das suas relaçôes com os outros, tanto as solidariedades quanto as hierarquias, então ele também entendeu as possibilidades de mobilidade social e reconhecimento abertas a homens como ele. A despeito da sua reputação, provavelmente acurada, de ser muito cioso do seu dinheiro e pouco afeito a gastos, ele certamente prestava uma atenção considerável na sua autoapresentação, e em seus raros momentos de lazer ou de apresentação pública fora do trabalho, podemos facilmente imaginá-lo vestindo seu costume preto, com sapatos, gravata de cetim e outros itens finos encontrados entre os pertences avaliados em seu inventário. Essas roupas e acessórios, exemplos do gosto europeu que se tornava cada vez mais na moda entre a elite brasileira, eram símbolos da moderna respeitabilidade burguesa que Augusto pode ter desejado para si mesmo. Seu gosto pela moda tornou-se possível pela circulação internacional de bens de consumo, como o seu chapéu de mola, o chapeau claque, um item de estilo elegante inventado na França algumas décadas antes. ${ }^{45}$

O que os documentos sobreviventes nos revelam sobre a curta vida de Augusto é muito limitado. É mesmo possível — como as autoridades certamente desconfiavam — que os objetos encontrados pela polícia tenham sido discretamente selecionados pelos seus companheiros de casa. Ao identificá-lo como um "preto mina", seus camaradas - eles mesmos oriundos de partes diferentes do continente africano - nos dão uma pista dos outros conjuntos de conexôes transcontinentais que são uma presença silenciosa na sua história pessoal. Talvez Augusto tenha trazido da Baía de Benin mais do que as marcas na sua pele e a língua que falava. Alguns dos seus costumes e valores, ou mesmo suas crenças religiosas, podem ter tomado inicialmente forma em seu lugar e cultura de origem. Ele poderia mesmo ter sido, como muitos outros "minas" inventivos e morigerados como ele, um homem de fé muçulmana ${ }^{46}$ Nenhuma dessas hipóteses poderia, naturalmente, ser abordada de modo convincente em uma apresentação como esta. Mas podemos certamente dizer que muito dos detalhes, assim como alguns aspectos de maior significado histórico da curta vida de Augusto, permanecerão tão obscuros para nós quanto a presença do "barrete de algodão colorido" que foi encontrado a desafiar a sobriedade cromática dos seus pertences. Talvez sinal de um gosto inteiramente particular, ou um objeto conectado as suas devoçôes, esse barrete nos ajuda a lembrar que os artefatos, tanto físicos quanto documentais, da vida de Augusto deixam sua história e seu lugar em um quadro mais amplo abertos para o debate futuro.

\footnotetext{
${ }^{45}$ COLONETTI, A. et alli (Org.). Cosa ti sei messo in testa. Storia e geografia del cappello. Milão: Mazzotta, 1991. ${ }^{46}$ Sobre os "minas" muçulmanos, ver KARASCH, Mary. A vida dos escravos no Rio de Janeiro 1808-1850. São Paulo: Companhia das Letras, 2000, p. 63-64; além de, obviamente: REIS, João José. Rebelião escrava no Brasil. A história do levante dos malês em 1835. Edição ampliada. São Paulo: Companhia das Letras, 2003. Do mesmo modo: REIS, João José; MAMIGONIAN, Beatriz G. Nagô and Mina: The Yoruba Diaspora in Brazil. In: FALOLA, Toyin; CHILDS, Matt D. (Org.). The Yoruba Diaspora in the Atlantic World. Bloomington: Indiana University Press, 2004, p. 77-110.
} 
Buscando no fundo do baú de Augusto podemos encontrar, junto com os vários objetos que deixou para trás, evidências de um mundo de conexôes intercontinentais que ajudaram a definir suas experiências e escolhas. Prestando atenção nos objetos que Augusto nos legou involuntariamente, também compreendemos que seu mundo - por mais estruturado e coerente quanto possa ter sido - era também lugar de ação autônoma, bem como de criatividade individual e coletiva. As condiçôes da vida de Augusto poderiam ser interpretadas como um resultado colateral de um processo através do qual as forças impessoais do mercado de trabalho livre vão substituindo um sistema obsoleto de administração de trabalho e de dominaçáo marcado pela escravidão e pelo domínio pessoal baseado na raça. E ainda, naquilo que esses processos econômicos e sociais de fato se manifestam no que podemos reconstruir de sua vida, emerge um quadro que coloca em questâo a validade de qualquer modelo coerente e unívoco de transição para formas "modernas" de relaçóes sociais e econômicas. ${ }^{47}$

Como vimos, a vida de Augusto exemplifica de modo enfático tanto amplos e abrangentes processos sociais, quanto incongruências, limites e brechas que os caracterizaram. Emerge daí que o novo mundo do trabalho "livre" esteve constantemente entrelaçado com, e redefinido por, reminiscências de um modelo aparentemente superado de administração de mão de obra, mas também - e talvez ainda mais — pela invenção ativa de novas formas de coação social e legal, assim como a constante negociação dos significados sociais e culturais da dependência pessoal e da autonomia, bem como a permanente redefinição de interesses comuns e coletivos. A realidade diária das relaçóes sociais e de trabalho, conflitos e solidariedades contribuíram para a criação, com todas as ambiguidades e promessas não cumpridas, do mundo do "trabalho livre" no qual ainda vivemos.

\section{Fontes documentais}

"Inventário de Augusto Africano Livre" (executor: José da Lapa Souza Coentro). Fundo (em processo de organizaçáo): Juizo de Órfãos da Cidade do Desterro, 1861 - Arquivo do Museu do Judiciário Catarinense (Florianópolis, SC).

\footnotetext{
${ }^{47}$ Os limites de um modelo de "transição" para o trabalho livre, entendido como a forma "moderna" que necessariamente substituiria a expropriação do trabalho escravo pelo trabalho assalariado da exploração capitalista, foram apontados por vários autores que, na última década, mostraram as dificuldades de se estabelecer limites claros entre o trabalho "livre" e "não livre", sobretudo no horizonte de expansão das formas de trabalho compulsório e forçado no mundo da expansão colonial do século XIX, do qual o Brasil faz, de muitos modos, parte. Para o caso brasileiro em especial, ainda valem as observaçôes feitas por Sílvia Hunold Lara em seu artigo sobre o tema: Escravidão, cidadania e história do trabalho no Brasil. Projeto História, v. 16, p. 25-38, 1998; ver também minhas próprias observaçôes sobre o assunto em: LIMA, Henrique Espada. Sob o domínio da precariedade: escravidão e os significados da liberdade de trabalho no século XIX. Topoi, v. 6, n. 11, p. 289-326, 2005.
} 
"Emancipação. Rufina Africana Livre". Fundo (em processo de organização): Juizo de Órfäos da Cidade do Desterro, 1861 - Arquivo do Museu do Judiciário Catarinense (Florianópolis, SC).

\section{Referências bibliográficas}

ALENCASTRO, Luís Felipe de. O trato dos viventes. Formação do Brasil no Atlântico Sul, séculos XVI e XVII. São Paulo: Companhia das Letras, 2000.

ARMITAGE, D.; BRADDICK, M. J. (Org.). The British Atlantic World, 1500-1800. Nova York: Palgrave Macmillan, 2002.

ARMITAGE, David; SUBRAHMANYAM, Sanjay (Org.). The Age of Revolutions in Global Context, c. 1760-1840. Nova York: Palgrave Macmillan, 2010.

ARMITAGE, David; GULDI, Jo. The History Manifesto. Cambridge, MA: Cambridge University Press, 2014.

- The History Manifesto: A Reply to Deborah Cohen and Peter Mandler. The American Historical Review, v. 120, n. 2, p. 543-554, 2015.

ASLANIAN, Sebouh David et al. AHR Conversation How Size Matters: The Question of Scale in History. The American Historical Review, v. 118, n. 5, p. 1431-1472, 2013.

BAYLIN, Bernard. Atlantic History: Concept and Contours. Cambridge: Harvard University Press, 2005.

BERTIN, Enidelce. Os meia-cara. Africanos livres em São Paulo no século XIX. Tese (Doutorado em História Social) — Universidade de São Paulo, São Paulo, 2006.

COGHE, Samuël. The Problem of Freedom in a Mid-Nineteenth-Century Slave Society: The Liberated Africans of the Anglo-Portuguese Mixed Comission in Luanda (1844-1870), Slavery \& Abolition, v. 33, n. 3, p. 479-500, 2012.

COHEN, Deborah; MANDLER, Peter. The history manifesto: A critique. The American Historical Review, v. 120, n. 2, p. 530-542, 2015.

COLONETTI, A. et al. (Org.). Cosa ti sei messo in testa. Storia e geografia del cappello. Milão: Mazzotta, 1991.

CONRAD, R. Neither Slave nor Free: The Emancipados of Brazil, 1818-1868. Hispanic American Historical Review, v. 53, n. 1, p. 50-70, 1973.

COOPER, Frederick. What Is the Concept of Globalization Good for? An African Historian's Perspective. African Affairs, v. 100, n. 399, 2001.

COSTA E SILVA, Alberto da. Um rio chamado Atlântico: a África no Brasil e o Brasil na África. Rio de Janeiro: Nova Fronteira, 2011. 
. Félix de Souza, mercador de escravos. Rio de Janeiro: Nova Fronteira, 2011.

CURTO, José C.; LOVEJOY, Paul E. (Org.). Enslaving Connections: Changing Cultures of Africa and Brazil During the Era of Slavery. Amherst, NY: Humanity Books, 2003.

DAVIS, David Brion. The Problem of Slavery in the Western Culture. Ithaca, NY: Cornell University Press, 1966.

. The Problem of Slavery in the Age of Revolution. Ithaca, NY: Cornell University Press, 1975.

. Looking at Slavery from Broader Perspectives. The American Historical Review, v. 105, n. 2, p. 452-466, abril 2000.

DOSSE, François. A história em migalhas. Dos annales à nova história. Campinas: Edunicamp/Ed. Ensaio, 1992.

DOUKI, Caroline; MINARD, Philippe. Histoire globale, histoires connectées: un changement d'échelle historiographique? Introduction. Revue d'histoire moderne et contemporaine, n. 54-4bis, p. 7-21, 2007/5.

ELEY, Geoff. A Crooked Line from Cultural History to the History of Society. Ann Arbor: Michigan University Press, 2005.

FERREIRA, Roquinaldo. Cross-Cultural Exchange in the Atlantic World: Angola and Brazil during the era of the slave trade. Nova York: Cambridge University Press, 2012.

FLORENTINO, Manolo. Em costas negras. Uma história do tráfico de escravos entre a África e o Rio de Janeiro. São Paulo: Companhia das Letras, 1997.

FRANK, Zephyr. Entre ricos e pobres: O mundo de Antonio José Dutra no Rio de Janeiro oitocentista. São Paulo/Belo Horizonte: Annablume/PPGH-UFMG, 2012.

GAMES, Alison; EGERTON, Douglas (Org.). The Atlantic World: A history, 1400-1888. Hoboken: Wiley-Blackwell, 2007.

GILROY, Paul. O Atlântico negro. Modernidade e dupla consciência. São Paulo/Rio de Janeiro: Ed. 34/Universidade Candido Mendes, 2001.

GINZBURG, Carlo. Latitudes, escravos e a Bíblia: um experimento em micro-história, Art Cultura, v. 9, n. 15, p. 85-98, jul.-dez. 2007.

GREENE, Jack; MORGAN, Philip (Org.). Atlantic History: A Critical Appraisal. Nova York: Oxford University Press, 2009.

HEWIT, V. (Org.). The Banker's Art: Studies in Paper Money. Londres: British Museum Press, 1995.

HOLT, Thomas. The Problem of Freedom: Race, Labor, and Politics in Jamaica and Britain, 1832-1938. Baltimore: Johns Hopkins University Press, 1991.

HÜBENER, Laura Machado. O comércio da cidade do Desterro no século XIX. Florianópolis: Ed. UFSC, 1981. 
KARASCH, Mary. A vida dos escravos no Rio de Janeiro 1808-1850. São Paulo: Companhia das Letras, 2000.

LAW, Robin; Kristin Mann. West Africa in the Atlantic Community: The Case of the Slave Coast. The William and Mary Quarterly, v. 56, n. 2, p. 307-334, 1999.

LARA, Sílvia Hunold. Escravidão, cidadania e história do trabalho no Brasil. Projeto História, v. 16, p. 25-38, 1998.

LIMA, Henrique Espada. Sob o domínio da precariedade: escravidão e os significados da liberdade de trabalho no século XIX. Topoi, v. 6, n. 11, p. 289-326, 2005.

. A micro-história italiana: escalas, indícios e singularidades. Rio de Janeiro: Civilização Brasileira, 2006.

LINDSAY, Lisa A.; SWEET, John W. (Org.). Biography and the Black Atlantic. Philadelphia: University of Pennsylvania Press, 2014.

LINEBAUGH, Peter; REDIKER, Marcus. A hidra de muitas cabeças. Marinheiros, escravos, plebeus e a história oculta do Atlântico revolucionário. São Paulo: Companhia das Letras, 2008.

MAMIGONIAN, Beatriz G. To be a Liberated African in Brazil: Labour and Citizenship in the Nineteenth Century. Tese (Doutorado em História) — University of Waterloo, Waterloo (CA), 2002.

MAMIGONIAN, Beatriz G. José Majolo e Francisco Moçambique, marinheiros das rotas atlânticas: notas sobre a reconstituição de trajetórias da era da Abolição. Topoi, v. 11, n. 20, p. 75-91, jan.-jun. 2010.

MAMIGONIAN, Beatriz G.; RACINE, Karen (Org.). The Human Tradition in the Black Atlantic, 1500-2000. Lanham, MD: Rowman \& Littlefield, 2009.

MARQUESE, Rafael de Bivar. As desventuras de um conceito: capitalismo histórico e historiografia sobre a escravidão brasileira. Revista de História, n. 169, p. 223-253, 2013.

MARQUESE, Rafael de Bivar; PARRON, Tâmis Peixoto. Internacional escravista: a política da segunda escravidão. Topoi, Rio de Janeiro, 12 (23), p. 97-117, 2011.

MILLER, Joseph. The Problem of Slavery as History: A Global Approach. New Haven: Yale University Press, 2009.

MOREIRA, Alinnie S. Liberdade tutelada: os africanos livres e as relaçôes de trabalho na Fábrica de Pólvora da Estrela, Serra da Estrela (c. 1831-c.1870). Dissertação (Mestrado em História), Universidade Estadual de Campinas, Campinas, 2005.

POPINIGIS, Fabiane. Aos pés dos pretos e pretas quitandeiras: experiências de trabalho e estratégias de vida em torno do primeiro mercado público do Desterro, 1840-1890. AfroÁsia, n. 46, p. 193-226, 2012.

PUTNAM, Lara. To Study the Fragments/Whole: Microhistory and the Atlantic World, Journal of Social History, v. 39, n. 3, p. 615-630, 2006. 
REIS, João José. Rebeliāo escrava no Brasil. A história do levante dos malês em 1835. Edição ampliada. São Paulo: Companhia das Letras, 2003.

REIS, João José; GOMES, Flávio dos Santos; CARVALHO, Marcus J. M. de. O alufá Rufino: tráfico, escravidão e liberdade no Atlântico negro. São Paulo: Companhia das Letras, 2010.

REIS, João José; MAMIGONIAN, Beatriz G., Nagô and Mina: The Yoruba Diaspora in Brazil. In: FALOLA, Toyin; CHILDS, Matt D. (Org.). The Yoruba Diaspora in the Atlantic World. Bloomington: Indiana University Press, 2004, p. 77-110.

REVEL, Jacques (Org.). Jogos de Escalas. A experiência da microanálise. Rio de Janeiro: FGV Editora, 1998.

RIELLO, Giorgio. La globalisation de l'histoire globale: une question disputée. Revue d'histoire moderne et contemporaine, 2007/5, n. 54-4bis, p. 23-33, 2007.

RUPPRECHT, Anita. 'When he gets among his Countrymen, they tell him that he is free': Slave Trade Abolition, Indentured Africans and a Royal Commission. Slavery \& Abolition, v. 33, n. 3, p. 435-455, 2012.

SAFELA, Babatunde, Emancipados Slave Societies in Brazil and Cuba. Trenton: African World Press, 2011.

SCHULER, Monica. "Alas, Alas, Kongo": A Social History of Indentured African Immigration into Jamaica, 1841-1865. Baltimore: Johns Hopkins University Press, 1980.

SCOTT, Rebecca J. Small-Scale Dynamics of Larger-Scale Processes. The American Historical Review, v. 105, n. 2, p. 472-479, 2000.

SCOTT, Rebecca J.; HÉBRARD, Jean. Freedom Papers: An Atlantic Odyssey in the Age of Emancipation. Cambridge: Harvard University Press, 2012.

SEWELL, William H. Logics of History: Social Theory and Social Transformation. Chicago: Chicago University Press, 2005.

SILVA, Antonio de Moraes. Diccionario da lingua portugueza. 2. ed. Lisboa: Typographia Lacerdina, 1813.

SILVA, Moisés et al. Relatório final da Pesquisa - Fontes para a História da Escravidão em Alagoas. (Macieó): Universidade Estadual de Alagoas, 2010, p. 241 (não publicado).

SPARKS, Randy J. The Two Princes of Calabar. An Eighteenth-Century Odissey. Cambridge: Harvard University Press, 2009.

SWEET, James H. Domingos Alvares, African Healing, and the Intellectual History of the Atlantic World. Chapel Hill: The University of North Carolina Press, 2011.

THORNTON, John. Africa and Africans in the Making of the Atlantic World, 1400-1800. Cambridge: Cambridge University Press, 1992.

TOMICH, Dale W. Pelo prisma da escravidão. Trabalho, capital e economia mundial. São Paulo: Edusp, 2011. 
TRIVELATTO, Francesca. Is There a Future of Italian Micro-History in the Age of Global History? California Italian Studies, v. 2, n. 1, 2011. Disponível em: <http://escholarship. org/uc/item/0z94n9hq>. Acesso em: 21 de janeiro de 2015.

VAN DER LINDEN, Marcel. The Promise and Challenges of Global Labor History, International Labor and Working Class History, v. 82, p. 57-76, outono de 2012.

. Trabalhadores do mundo: ensaios para uma história global do trabalho. Campinas: Edunicamp, 2013.

VAN DER LINDEN, Marcel; LUCASSEN, Jan. Prolegomena for a Global Labour History. Amsterdam: International Institute of Social History, 1999.

VAN DER LINDEN, Marcel; MOHAPATRA, Prabhu (Org.). Labour Matters: towards global histories. Nova Deli: Tulika Books, 2009.

VERGER, Pierre. Fluxo e refluxo do tráfico de escravos do Golfo do Benin e a Bahia de Todos os Santos dos séculos XVII a XIX. Salvador: Corrupio, 1987.

WILDER, Gary. From Optic to Topic: The Foreclosure Effect of Historiographic Turns. American Historical Review, v. 117 (3), p. 723-745, 2012.

WIMMER, Andreas; SCHILLER, Nina G. Methodological nationalism and beyond: nation-state building, migration and the social sciences. Global Networks, v. 2, n. 4, p. 301334, 2002.

ZUNIGA, Jean-Paul, L'Histoire Impériale à l'heure de l'histoire globale'. Une perspective atlantique. Revue d'histoire moderne et contemporaine, n. 54-4bis, p. 57, 2007/5. 